\title{
Students' assessment and class management: A critical Approach
}

\author{
Ervin Balla ${ }^{1} \mathrm{PhD}(\mathrm{c})$
}

\begin{abstract}
We know that the teaching method is effective only if it reaches the targets of the program. Teaching the students in each level should be tested. The assessment and the testing of the students are important parts of teaching and learning process. The students learn very well in classes is constant and is part of student's expectations. The assessment can be done in various ways, through testing at the end of the term, or can be done continuously. However testing and assessment should be taken really seriously if we want to achieve high results in our work as English teachers. Also the class management plays an important part in the process of teaching-leaning and it is closely connected to the assessment and testing of the students.
\end{abstract}

Key words: assessment, class management, teaching, learning. testing

\section{Students' assessment}

The only indicator that the method of teaching is effective is if it reaches the targets of the program and to what we teach to the students. Teaching the students at each level should be tested in a way or another. As (McInemey and McInemey 2005) say that the testing and the assessment of the students are an integral part of teaching and learning in general. (Kauchak and Eugene 2005) confirm that: "the relationship between learning and assessment is clear and consistent. The students learn more in classes where the assessment is a regular part of the education routine, especially when the assessment is continuous and gives an answer to the student expectation.

The terms assessment and testing of the knowledge are used frequently instead of each other, with the term "testing of knowledge" refers to the process of collection of information from the students, while the term assessment means to see this information and to take some decisions regarding this information. The main purpose of assessment is:

To make able a teacher in an effective assessment of the program of teaching and to make the necessary changes in the method of teaching, activity of learning or sources of this process

- To identify each student that may have difficulty in the perception of the content of the course lectures and to add in this way the necessary aid 
- To give information if a student should be transferred from one school to another or to refer to specific education

- To be valuable for the parents and to give them evidences for the improvement of their children

- $\quad$ To be valuable for the educational authorities and to give to them evidences for the levels of achievement in the schools

In the majority of the schools the most usual method for the assessment of the students is through regular testing of the students and observation. In a formal level, the exams can be used to collect information in the middle or in the end of the semester. In another formal level the test can be the state or national testing.

There exist many methods besides testing to gain information over the progress of the student. Teacher can even use these methods even during the class.

According to (Airasian 2005) the planned observation is a natural and important mean for the observation and assessment of the class. The observations are much more valuable than formal testing, because they can be performed in modest way and very frequently give more information than the instruments of formal testing.

Very frequently they can give extra information in various fields such as: the application of knowledge, the reasoning of the students and the solution of the problems (Borich 2003) considers the observation of abilities of the students as an essential assistance for the effective learning. The observation of the students allows teachers perform what is considered authentic assessment (Burke 20015)

The term authentic assessment uses those assignments that the students do during their classes than the use of the assessment paper used for this purpose. In peculiar, the observation is important to assess the social abilities, job customs, behaviour interest and self management. The features of the assessment are part of "dynamic assessment "especially when the students have problems in learning.

The term "dynamic assessment" explains a situation where a given assignment is given to a student. First he tries to do the assignment without help. The teacher observes the performance and if in some cases he thinks that it is not good, he decides what information or knowledge needs the student to complete the assignment completely. Than the teacher observes the student and finds out how the student has learned from its instructions. If the first attempt of re-learning was not very accurate the teacher should try again, using another method, or giving an additional extra time, quite differently from the standard testing where the standard procedures should be followed.

\section{Class management}

The class management has a special importance when we talk about the teaching of grown up students. The teacher is not an authoritarian figure in the class, which places his veto. The teacher of grown up students should change and develop important abilities for this group age of students. The grown up students know very well what they like in a teacher. We come to work with a well shaped personality, but however there are abilities and behaviour that can be learned and worked. As a teacher of grown up students it helps us a great deal if we have a sense of humour, are open minded, 
adaptable, patient etc, but even if we don't have these abilities we can work to change our behaviour, or abilities (Broughton G. 2002).

The behaviour of the teacher of the language is an important factor for the motivation of the students and this is reflected in the teaching learning process and improvement of the students. They become more cooperative. This is noted by the higher participation during classes, greater attention to the explanation of the teachers etc.

In this way the class management of the class becomes easier and the challenges that come across are easier to surpass. The contrary will happen in the cases when the behaviour of the teacher is not very good, he seeks to impose his authority with other authoritarian ways, rather than what are considered professional. The cooperation during the class will be difficult if our students are grownups. The attention will be lowered and the communication will be impossible.

The restoration of the authority of the teacher will be done if the teacher owns very well the subject is competent for what he says and respects the opinion of the students. All these restore a cooperating bridge which is the key chain for the activities and learning of the English language. Besides what we mentioned there are also many other factors that are valuable for the effective management of the class, that I have taken into consideration below.

The teacher should be realistic for what the students can manage in the individual level, so our expectation should be realistic too. As an English teacher we should appear to the students in the same way too. It would be a great distinction if we should feel secured in our actions. The teacher should know at every moment what is doing. We can build our safety by planning reading, assessing and talking to others. Once the students feel safer and quite in the classroom, they can be encouraged to move forward with the learning of the new language. The safety is not a behaviour or ability but is valuable if we want our students to gain the maximum of the language.

As we stated earlier we should know what we are doing. The students should know what they are doing and they need to feel that they are improving in the learning of the new language. The strengthening of the belief in them that the learning of the language is a continuous process and valuable that will lead inevitably to the idea that the mastering the English language is not unachievable, but a challenge that can be surpassed with effort (Farrel C. Jacobs G. 2010). The creation of security to the students is tightly connected with the respect of the students and their strategies of learning.

Anytime that a student tries to tell something, we should accept the mistakes that he makes too. The direct correction is not very effective and does not influence in the creation of a good atmosphere in the class. The grownups do not like to be corrected in the class and in the presence of their friends, the correction in an indirect way, an advice would be much more successful and helpful. It would take place when we work in language exercises but not when we use the language for communication.

The ideal students would be those students that do not laugh in class by the mistakes of their friends, and this can be as a rule of class. One of the best keys to learn the foreign is the encouragement to talk in the foreign language in the class, if these students pass this stage and dare to communicate in this language, good results can be achieved. The best thing to do in these cases is to make clear to the students that everybody makes mistakes when they talk in a foreign language.

Even the placement of the routine is something important for both parties, teacher and the students. The teacher should greet when they come to class and ask the students do 
the same thing. The discussion in the foreign language for different things out of the topic would help in the enrichment of the vocabulary with words and expressions from the everyday life such as school, life, family life in the foreign language we would build self confidence to our students. They are always willing to do those things, and they are always available to discuss and give their opinion regarding those issues. These are successful language activities that involve the responsibility for the language learning and helping other in foreign language learning.

\section{Placement of targets and purposes}

In the stage of planning of our lessons we very frequently need to restore our purposes and targets that we should achieve (Rogers T, Richard J 2001). Simple purposes may involve for i.e. lesson reviewing and practicing of present perfect tense in English language. The increasing of the ratio between students. Another purpose could be learning the vocabulary that has to do with interests and desires of the students. One of the purposes that always attracts the attention during the classes, since the majority of them likes the branch of study that have chosen to study is the vocabulary and the situations built in their field of study. The teaching of the students to express the things that they like and don't like using the structure like plus gerund.

The targets are abilities that we wish that the students be able to demonstrate in the end of the class for his achievements during the class. The targets may involve specific purposes that the student should be able to compare his experience in travelling with other students using the expressions "have you ever"...? To write a questionnaire using verbs accompanied with travelling in the present perfect and compare it with other students. They have to learn the vocabulary for their pleasure and interest, involving the accurate pronunciation of the words. They should know when to use the gerund and when to use the noun. They have to learn to discuss about the interests and desires compared to other groups of students.

Even when we are in a conversation in the classroom, we should have a clear idea about what we want to achieve in the classroom. Together we and our students gain when we write our purposes and targets. We consider the lesson from both point of views, from our point of views and from their point of views. If we place purposes and targets it is less likely to side pass during the classes and be focused in things that are important to be achieved and the attempts to achieve these things. We can evaluate the effectiveness of activity that we intend to use only by checking if these things are closely connected to the targets and aim of the lesson.

\section{Stuff used for lesson}

We can start asking ourselves: what can the materials do? In determining their purpose we can establish some aims that can lead us in the selection of the materials (Harmer J. 2002)

i. Materials give stimuli to learn. The good materials do not teach, they encourage students to learn. The good materials should contain:

- $\quad$ Interesting texts

- $\quad$ Pleasing activities that engage capacities of thinking for students 
- $\quad$ Possibilities for students to use their existing abilities and their abilities

- $\quad$ Contents fit for students and teachers

The materials help to organize the process of teaching and learning making a new way to the complexity of the language itself. The good materials should introduce in a clear and coherent way, which will lead the teachers and students through different activities maximizing the opportunities for the language learning. This structure should help the teachers in the lesson planning and encourage to the students a feeling of progress and achievement. On the other side the materials should not be very structured or produce a monotony, as it would be for i.e. all the texts would look the same, the same illustration, the same exercises etc. a model of materials should be clear and systematic, also very flexible to allow hw creativity and multitude.

ii. The materials shape a point of view of nature of language and teaching. In writing the materials we as the authors can give all our opinions in what consists the learning of the foreign language, so the materials should reflect what we feel and think for the process of teaching and learning. If we think that the students learn when their capacities of their learning are committed then we should not write exercises that ask a little or none active thinking. If we think that learning and teaching increases with a continuous experience then we should not provide texts which have no any kind of human interest. If we think that learning is influenced by the continuous repetition then we make sure that the topics we discuss repeat time after time.

iii. We have noticed above that the teaching of the language is a complex process that involves many kinds and different levels of knowledge

iv. The materials may have a very valuable function in the extension of the training of the teachers, introducing the teacher to new techniques. They give models of the correct and appropriate use of the language.

Taking into consideration those things that we mentioned above we can introduce a model that we can use in the completion of the materials. The purpose of this specific model is to give a coherent frame for the integration of different aspects of lesson, while at the same time to allow the necessary space for creativity and variation. This model consists in four elements; input, focus on content, focus on language and assignment.

i. Input: can be a text, dialogue, video registration, diagram or any other part of communication according to the needs that we may have defined in our analysis. The input gives us many things.

- $\quad$ Stimulating materials for activities

- New linguistic articles

- $\quad$ Correct models for the use of language

- A new topic for communication

- Possibilities for students to use their knowledge

ii. Focus in content: The language is not a conclusion within itself, but a mean of transport of information for something or about something. The non verbal communication should be used to generate communication in the class.

iii. Focus in Language: our purpose is to make the students able to use the language, but it is not fair to give to them assignments or class works for which they have not the linguistic skills. The good materials should involve even the abilities to analysis and 
synthesis. In the language focus the students should have the opportunity to break the language, to see how it works and then put it back together.

iv. Assignments. The last purpose of the improvement of the language is the use of the language. The materials should be projected, specifically toward this purpose. The more we use the language the better is.

\section{Conclusions}

As we saw from the article, the student' assessment is very important for the teaching and learning process. It encourages students to learn the language, and in this aspect we as teachers of English language reach also our goal. Also the class management is important and all the factors related to it should always be taken into consideration.

\section{References:}

Corder N., 'Learning to teach adults' 2002 Routledge Falmer

Richards J. 'Approaches and methods in language teaching' 2001 Cambridge University press

Heargraves A. (1992) "Teacher development and educational change" Routledge USA

Hutchinson T., (1987) "English for specific purpose" Kembridge University Press.

Corder N., (2008) "Learning to teach adults" Routledge

Harmer J., (2010) "How to teach English" Pearson Longman

Hutchinson T., \& Waters A, (1987), "English for specific purposes", Cambridge University Press

Tamo A, Rapti E, Karaj Th, (2005), "Mësimdhënia dhe të nxënif", Tiranë , Mokra,

Aliu I., (2004) "Metodologiz e mësimnxënies", Tirane Pegi

Lynch T., (1996)" Communication in the language classroom", Oxford

Thomas S. Farrell C and George M. Jacobs (2010) "Essentials for Successful English Language Teaching" Continuum

Diller, K. C., (1971). “Generative Grammar, Structural Linguistics, and Language Teaching: Newbury House Publishers

Coleman, A., (2012) "The Teacbing of Modern Foreign Languages in the United States". Literary Licensing, LLC

Howatt, A. P. R., (198 4) "A History of English Language Teaching". Oxford University Press

Gauntlett J. O., (1957) "Teaching English as a Foreign Language". London: Macmillan

Palmer, H. E., (1968), "The Scientific Study and Teaching of Languages". London: Oxford University Press,

Thorne. K., (2003) "Blended Learning: How to Integrate Online and Traditional Learning" Great Britain Clays

Macdonald J., (2008) "Blended learning and online tutoring" England, Gower publishing

Palmer, H. E. (1934) "Specimens of English Construction Patterns". Department of Education

Billows, F. L. , (1961). "The Techniques of Language Teaching. London": Longman

]akobovits, L. A., (1970). "Foreign Language Learning: A Psycho linguistic Analysis of the Issues". Newbury House

Bentley T., (1998) "Learning beyond the classroom " Routledge

Richard J and Rodgers Th., (2001) "Approaches and methods in language teaching" Cambridge University Press 